\title{
Quality in Higher Education: From the Diversity of Conceptions to the Relentless Conceptual Subjectivity
}

\author{
Julio C. G. Bertolin \\ Postgraduate Program in Education, University of Passo Fundo, Passo Fundo, Brazil \\ Email: julio@upf.br
}

Received 26 November 2015; accepted 22 December 2015; published 25 December 2015

Copyright ( 2015 by author and Scientific Research Publishing Inc.

This work is licensed under the Creative Commons Attribution International License (CC BY).

http://creativecommons.org/licenses/by/4.0/

(c) (i) Open Access

\begin{abstract}
The current article approaches and assesses the different conceptions and understandings of quality in the higher education scope. Initially, the text reviews the concepts of quality based on the taxonomies presented by the top researchers approaching this subject; next, it shows a list of terms that have been recently identified according to the views of quality in higher education, such as economic competitiveness and market growth, sustainable sociocultural and economic development or, yet, to a view of higher education that has the prior mission of social cohesion and equity. Finally, the relentless conceptual relativity of quality in the higher education is approached.
\end{abstract}

Keywords

Higher Education, Quality in Higher Education, Higher Education Conceptions

\section{Introduction}

It is most likely that one of the most used words in the papers and researches in the higher education (HE) field, in the last few years, is "quality". The emphasis given to the debate about quality is preceded by quantitative demands. The peak of the quantitative solutions in education took place in the 1960s and 1970s. These solutions are expressed through the increase in expenses with education in many countries, through the increase in the number of years spent in compulsory education, through the early age children being admitted in school and through the development of economic theses about education, such as the "theory of human capital", which is used to explain the economic growth in these countries. The first arguments about quality in education just emerged in the early 1980s; and by the end of the decade, the subject became priority in the USA and in Europe. 
An environment appropriate to the development and creation of quality in higher education takes the scene worldwide, since it has been recently facing "hostile" factors and challenges such as financial limitations, competition among institutions, massification of systems, teachers' demotivation, institutional autonomy, etc. In many cases, such programs have a close link with the management conceptions from the industrial sector. These conceptions emphasize efficiency, productivity and cost reduction aspects. Characteristic terms from the private sector, from companies and from the market such as, for instance, strategic planning, total quality and audits become part of the routine in higher education institutions and in universities. Such quality programs developed to the academic component have often failed (Santiago, 1999). Those who advocate for the business quality models (total quality management, total quality, etc.) state that such fact results from some characteristics found in the academia, such as the resistance to the sense of student as a client, the hard time working as a team, tradition and the resistance to new practices, among others. On the other hand, other theses state the inadequacy of the industrial concept of quality to higher education due to the qualitative nature of teaching and researching, since these practices cannot be translated into a management and business logics.

Over the past few years, the main investigative studies on quality in HE are an attempt to answer questions related to the existence of quality itself-Would the development of mass education mean the end of quality? and to other issues that have emerged due to the significant prominence that the evaluation systems and the quality assurance have experienced in the last decades-Would the external evaluation be living in last days? Is the bureaucratization of the meaning of quality misused by the higher education globalized market, and does it mean that just the best ones will survive (Harvey, 2002)?

Regardless of the current prioritization of such approaches, it is still possible observing a broad diversity and certain disarray in the conceptual use of the term "quality" in the higher education scope. The differences in the understanding and in the application of the term promote a sort of trivial use of it. Therefore, the researches approaching such subject still require an introductory study about the understanding of quality in the higher education scope. The current text reviews the conceptions of quality based on the taxonomies presented by the top researchers in this subject; next, it presents a list of terms that have been more recently identified according to the views of quality; and finally, it approaches the relentless conceptual relativity of quality in HE.

\section{The Taxonomy Propositions to Quality in HE}

Many definitions of quality emerged in the 1980s. In 1983, Groot stated that quality is set by the degree in which a previous group of goals are met; in 1985, C. Ball defined quality as fitness for purpose and, right after that, quality was discussed in terms of added value by T. Barnett, in 1988, and by J. C. McClain, D. W. Krueger and T. Taylor, in 1989 (Watty, 2005). The main categorization propositions regarding the different ways to think quality in the HE emerged in the 1990s. Barnett (1992), in the article "improving higher education" in "the society for research into higher education", stated that it is not possible forming a consistent opinion about quality in HE without having a reasonable conception of higher education itself. According to the other author, the modern world does not have only one or two different conceptions, but many, due to the plural views in democratic societies. According to Barnett, there are four prevalent understandings able to support contemporary higher education approaches: (i) higher education as the production of qualified human resources; (ii) higher education as training for a researcher's carrier; (iii) higher education as the effective management of the available teaching practices and; (iv) higher education as a way to broaden the opportunities in life.

Barnett suggested the "objectivist, relativist and developmental" conceptions of quality. The objectivist view emphasizes that it is possible identifying and quantifying certain aspects of higher education, which are able to be universally applied to all institutions; whereas the relativist approach emphasizes the public policy and the theoretical basis. Barnett exposes the limitations of such approaches stating that the first one is highly insensitive to the existing differences among higher education institutions, and that the second one requires a clear definition of what can be currently considered as "higher education". Due to such limitations, the author suggested a third perspective called "quality developmental approach". According to such approach, the members in the organization are subjected to self-evaluation in order to focus on quality enhancement in the institution (Sahney, Banwet, \& Karunes, 2004).

Harvey \& Green (1993) published the most known quality classification proposal in HE in the journal "Assessment \& Evaluation in Higher Education". In the article called "Defining Quality", the authors compiled the 
broad diversity of existing conceptions within five distinct groups:

- Quality as an exceptional phenomenon: this quality conception accepts the axiom that quality is something special. According to this vision of quality, three variations can be observed: (a) the traditional vision of quality - corresponds to the idea of exclusivity, elitism and distinction, for instance, the education from Oxford and Cambridge, which is often inaccessible to most people. In this sense, quality cannot be measured or judged; (b) quality as excellence-quality is seen as the overcoming of standards. The components of excellence are identifiable in the inputs, in the process and in the outputs. The university that attracts the best students, the best professors (Nobel Prize winners) and that has the best physical resources (laboratories, libraries, etc.) is, by nature, the one that has the best quality and excellence (or a center of excellence); (c) quality as the fulfillment of a set of requirements-in this sense, quality results from "the scientific control of quality" due to its conformity to the standards. It is often linked to products that overcome "the quality control", i.e. quality improves if the standards are high.

- Quality as perfection or coherence: this conception of quality emphasizes the process and sets specifications that must be perfectly fulfilled; it is different from the sense of excellence, since it is available to all. At this point, excellence is redefined in terms of conformity to a set of action specifications, thus abandoning the idea of exceeding the standards. The keyword in quality is loyalty to the standards. This conception is linked to the "culture of quality", and it supposes that each member in the institution is responsible for the quality. As it reestablishes the excellence in terms of specifications and process, rather than in terms of inputs and outputs, this conception "democratizes" and "relativizes" quality.

- Quality as the fitness for purpose: according this conception, there is quality as long as the product or the service is adjusted to the satisfaction demands it was conceived and performed to. This is a functional definition of quality. A "perfect" product is totally useless if it does not satisfy the needs it was created to meet. The clients, suppliers or even the aims of the processes may set the purposes to which the product or service was created for; initially, the client is sovereign to define the purpose.

- Quality as a cost-benefit relation: the idea of economic efficiency lies on the basis of this conception of quality, i.e. the idea of accountability of costs (investments and defrayal) to the financers (government and taxpayers) is the core factor. The so called "performance indicators" are used as measurement in this conception of quality.

- Quality as transformation: the conception of quality is strongly linked to the sense of qualitative change. When it comes to education, the provider (professor or institution) does not do something for the student, but to the client; the provider changes the client. Thus, quality is, on one hand, developing consumers' capacities (student) and, on the other hand, it makes it possible to students to influence their own change. Quality is either, the "added value" to the student, in terms of knowledge, skill and ability enhancement, and also the capacity to enlighten the student, to increase his/her self-confidence and critical reasoning.

Green (1994), in the title "What is quality in higher education?", presented quality understanding categories in $\mathrm{HE}$, their respective advantages and disadvantages after approaching important aspects associated with quality in HE such as the causes for the growing interest in the subject and the need of asking "quality of what?" before defining quality:

- The traditional concept of quality: this concept is linked to the idea of offering a quite special and distinct product or service as a way to give status to its users. Concepts related to exclusivity and to high production standards are associated with this concept and, consequently, such products or services are not available to most of the population.

- Quality as the adjustment to specifications and to standards: the concept of quality in HE as an adjustment to specifications and standards resulted from the sense of quality control in the industrial production. The specification of a product or service holds a set of standards; and quality is measured in terms of conformity to certain specifications.

- Quality as the adequacy to the aims: the definition of quality adopted by many higher education analysts and police makers deal with adequacy to the aims. According to this concept, quality is judged in terms of the extent in which the preset aims of a product or service are achieved or accomplished.

- Quality as the achievement of the institutional targets: this concept is a version of the model that sees quality as the adequacy to the aims, the model that emphasizes quality evaluation at the institutional level. The high institutional quality is found in the explicit exposition of the institutions' mission and goals and to the efficiency and effectiveness in meeting self-determined targets. 
- Quality as client satisfaction: during the 1970s and 1980s, the definition of quality was often linked to the industry, and it only followed the sense of conformity to specifications related to the needs of clients. According to the concept resulting from the culture of quality as client satisfaction, priority was given to the identification of clients' needs, and it was the crucial factor to the development of new products and services. If one makes the option for using this definition of quality, it becomes clear that the adequacy to the aims is related to the clients' needs. However, when it comes to higher education, it is worth asking: Who is the client in the higher education? Is it the user of the service (the student) or is it the one who pays for the service (the government, the employers)? Is the student the client, or is it the product, or is it both? Some critics of the approach of quality in higher education argue whether the students are or not in the position of knowing what they actually need. Students may be in the position to identify what they need in the short term, but they probably do not have enough knowledge and experience to know what they need in the long term.

According to David Woodhouse (OECD, 1999: p. 29), among much of what was written about the meaning of quality in HE and among the many suggested definitions of it, the most often accepted idea of quality is linked to "fitness for purpose". According to the author, this concept of quality "allows institutions to define their purposes, their missions and their aims, thus 'quality' is shown by the achievement of such items”; fact that would also enable the existence of a variety of institutions. According to Watty (2005), the classification suggested by Harvey \& Green (1993) consists of a rigorous attempt to clarify how so many groups of interests or stakeholders ${ }^{1}$ understand quality. Actually, as for the classifications suggested by Barnett (1992), Harvey \& Green (1993) and Green (1994), except for the case of quality as fitness for purpose, all the other categories seem to be associated with some specific stakeholder. Notwithstanding, at the end, an approach of quality as "fitness for purpose" also depends on the values and priorities of the stakeholder who defines the purposes. This relation between the categories suggested by Harvey and Green and the groups of interest has been referred or applied as the structure to researches and discussions about the stakeholders' concepts of quality in HE, even when there are changes in some instances (Watty, 2005). The next text presents concepts based on the presented classifications and on the analysis of new terms applied to the subject; it presents concepts, synonyms and the tendency of concepts of quality in HE, which are grouped according to the identity and the similarity of concepts, and to the conception of higher education as a whole.

\section{New Terms and Tendencies of Quality in HE: Economicism, Pluralism and Equity}

Since the propositions of quality taxonomies in HE published in the 1990s, such as those described above by Barnett (1992), Harvey \& Green (1993) and Green (1994), the specialized literature did not present significant innovations about studies on the classifications and concepts in this subject. Thus, the most recent scientific studies and articles about quality in HE (Morosini, 2001; Vlãsceanu, Grünberg, \& Pârlea, 2004; Sahney, Banwet, \& Karunes, 2004; De la Orden Hoz, 1997; Harvey, 2005; Watty, 2005; Harvey, 2004; Mizikaci, 2006) often include reviews about the categories and conceptions of quality suggested in the last decade. Notwithstanding, in the last few years, the emergence of new terms to explain the properties of quality in HE has been observed. Probably, such fact due to the development of researches based on the new perspectives and on the involvement of a larger diversity of stakeholders and international organs with the following subjects: evaluation, measurement and quality assurance in education.

One single term could acquire meanings from different views in this context of development and innovation in HE quality and. On the other hand, one single meaning may have different terms to define it. However, such terms seem to have emerged along with two of the main ideas about the missions of higher education in the early XXI century: (Unesco, 1998; Amaral, 2002; World Bank, 2002; Brazil, 2003; Santos, 2004; Dias Sobrinho, 2005) (a) economic competitiveness and market growth and (b) sustainable sociocultural and economic development; or, yet, to a view of higher education that has the prior mission of (c) social cohesion and equity (Unesco, 1998; Morosini, 2001). Such link between the conception of education and the concepts of quality seem to give reason to the assumption by Barnett (1992) according to whom it is not possible to have a consistent opinion about quality in HE without having a reasonable conception of higher education itself. According to Berto-

\footnotetext{
${ }^{1}$ The term stakeholder in the current text refers to the existing groups of interest associated with higher education and with its quality; among them, we highlight the government, teachers, students, technicians and employers. "In the context of higher education quality, stakeholders are those groups that have inter alia an interest in the quality of provision and standard of outcomes. These include government, employers, students, academic and administrative staff, institutional managers, prospective students and their parents taxpayers” (Harvey, 2004).
} 
lin (2007), it is possible grouping the most used terms about quality in three different tendencies of quality concept in HE, namely: the economicist view, the pluralist view and the view of equity (Table 1).

\subsection{The Terms of the Economicist View of Quality in HE}

In times of neoliberalism, the concept that higher education has the main aim of boosting the economic growth and of preparing individuals to the labor market is in great evidence. According to such logic, besides leading their services to the economic interests and training graduates especially for the labor market, the institutions must be as efficient and effective as possible, so that their aims are reached with lower costs and as fast as possible, i.e. it is a broadly economicist view, which refers to a prior instrumental and productivist perspective of higher education. The main groups of interest and of defenders of this idea are those linked to the private sector, such as companies and market organizations, as well as governments clearly identified with the neoliberal ideas concerning the minimal state and the fiscal adjustment. Some multilateral international organizations such as OCDE also agree, in some aspects, with these ideas and missions in the higher education.

The document called "Quality and Internationalization in Higher Education", from the OCDE, clearly shows the link between this conception of higher education and the matter of quality.

Because of the increase in (public resources for the higher education), there was a relative increase in the role played by the government to assure three framings. In the first place, are the higher education institutions (HEI) clearly planed and organized to produce the graduated individuals demanded by society, i.e. are their goals appropriate? In the second place, is the money being well spent, i.e. are the IESs presenting an efficient operation? And, in third place, are the HEIs producing the desired egresses, i.e. are they presenting an efficient operation?

These questions have been leading to new interpretations of the concept of quality (OECD, 1999: p. 29).

Some of the main terms used by those who present an economicist view of higher education refer to quality as "efficiency" and "employability". In terms of great market competitiveness and cost reduction, the word "efficiency" became a sort of basic requirement to many public and private management fields, as well as to a significant fraction of society, when it comes to taxation and public resources. As for the higher education, "efficiency" emerges from the core of neoliberal reforms in the State and in the educational system itself. According to the multidimensional paradigm of education administration suggested by Sander (1995), which is quite used in studies about quality in HE, in business and production engineering courses, "management efficiency" is a criterion of economic nature measured in terms of the management capability to reach high productivity levels.

According to Estrada (1999), the word "efficiency", within the quality context in HE, is part of the explanatory-relational dimension of quality, and it means the relation between the applied resources and the accomplishment of targets. According to Fazendeiro (2002), education must gather the desired and observable attributes (among others) in the efficiency and effectiveness dimension of the management resources in order to have quality, fact that demands excellence in governance. According to Unesco's glossary, education efficiency is defined as:

The ability to perform well or to achieve a certain result, without wasting resources, time, efforts or money (using the least amount of possible resources). Educational efficiency can be measured in physical terms

Table 1. Concepts of quality in higher education.

\begin{tabular}{|c|c|c|c|}
\hline Quality View & Associated Terms & Groups of Interest & Purposes of HE \\
\hline Economicist View & $\begin{array}{l}\text { Applicability and } \\
\text { efficiency }\end{array}$ & $\begin{array}{l}\text { Private sector, OCDE and } \\
\text { governmental sector }\end{array}$ & $\begin{array}{l}\text { Emphasis on aspects to boost the economic } \\
\text { growth and the applicability }\end{array}$ \\
\hline Pluralist View & $\begin{array}{l}\text { Differentiation, } \\
\text { relevance and pertinence }\end{array}$ & $\begin{array}{l}\text { Unesco, European Union and the } \\
\text { education sector }\end{array}$ & $\begin{array}{c}\text { Diversity of relevant aspects } \\
\text { (economy, sociocultural, democracy, etc.) } \\
\text { emphasizing the emergence of local specificities. }\end{array}$ \\
\hline View of Equity & Equity & Unesco and education sector & Emphasis on the aspects of contribution to social cohesion \\
\hline
\end{tabular}

Source: Author, based on Bertolin (2007). 
(technical efficiency) or in terms of cost (economic efficiency). A great educational efficiency is reached when the same amount and standard of educational services are produced at lower cost, when a useful educational activity is replaced by a less useful one at the same cost, or when unnecessary educational activities are eliminated (Vlãsceanu, Grünberg, \& Pârlea, 2004: p. 37).

In short, the term "efficiency" in the HE quality context has been mainly used in a sense related to economic and management issues, which encompasses cost rationality, high productivity and high business-managerial performance.

The idea that higher education is fundamental to the economic development of countries is not recent. However, many authors have indicated that the pressure over the educational system to effectively help the economic development and to prioritize the preparation to the labor market has increased in the last decades (Morosini, 2001). Such tendency has been leading to the concept of employability in functions and priorities of higher education. According to Harvey (2002), the idea of employability emerged in the debate about quality in the mid1990s. Most recently, we have been observing a phenomenon related to employability, it is quite similar to what has happened with TQM, in which the concepts of employability were "embraced" by some sectors of higher education and formed long and endless discussions about its concepts, applicability and appropriate language. Lee Harvey criticizes the understanding of employability as number of graduated professionals who get a full time job within a certain period of time, i.e. he refutes the understanding of employability as a result.

According to Morosini, employability, within the higher education scope, is not just getting jobs to graduates, not even just developing the employability skills. It is, actually, something much more complex and related to the "development of criticism within the process of continuous learning" (Morosini, 2001: p. 92). According to Harvey (2004), employability means the tendency of a graduated individual to show the attributes that employers anticipate as necessary to the effective future functioning of their companies. Employability is becoming an important term in the debate about quality in HE, regardless of some disagreements about its real meaning. Seminars and research centers have raised a discussion on the subject within the higher education scope.

Another subject identified with the view that higher education is associated with the economy or with the market is the total quality management. TQM, besides not being directly cited by the international organs, has been the object of many academic researches related to quality in HE. De la Orden Hoz (1997), in a recent article, highlights that a significant part of the existing literature about quality in education comes from the management perspective: quality control, audit and valuation, which involve total quality models such as the Balanced Scorecard and TQM. The application of the philosophy and theories of TQM to the educational sector still attracts the interest of many researchers and professionals; and, consequently, the educational system experiences the implementation of TQM.

According to Santiago (1999), the management process in education institutions gradually got closer to industrial practices by becoming a mainstream subject in higher education and by often adopting the management models of companies in the market. As per Gentilli \& Silva (1995), the neoliberalism from the 1990s brought a new way of looking at the educational quality; it associated HE with the marketing principles of productivity and profitability, and it introduced the logic of competition in the schools. Such reasoning is based on the belief that as much "productive" terms are applied to education, more "productive" the educational system becomes, i.e. it is the concept of quality that results from the logic of "total quality" in the business world.

According to Sahney, Banwet \& Karunes (2004), TQM is a process focused on the client, and it attempts to achieve continuous quality improvement through clients' perception; accordingly, its most complex theme concerns how to promote the maximum satisfaction for clients within a context of profile diversification involving people from different levels and positions. Many scientific studies criticizing the application of TQM to the higher education have emerged in the last decades; these authors argue that the industrial quality models are not applicable to the higher education (Gentilli \& Silva, 1995) and that it is worth considering the possibility of having this movement raising up against the organizational identity of universities and generating tension between the inflection of the higher education management and the changes that may be produced by the mischaracterization of the institution's identity (Santiago, 1999).

Many authors have alerted that the productivist view and the higher education evaluation developed according to the economicist view may critically translate procedures from the economic control into the educational and scientific production processes, thus bringing negative consequences along (Leite, 2003; Rodrigues Dias, 2003; De la Orden Hoz, 1997; Dias Sobrinho, 2005).

Many of the categories proposed back in the 1990s to classify quality in HE may be identified as an econo- 
micist and productivist view of the higher education such as, for instance, higher education as the product of qualified human resources, higher education as the efficient management of the available teaching practices (Barnett, 1992), quality as perfection or coherence, quality as cost-benefit relation (Harvey \& Green, 1993), quality as clients' satisfaction and quality as adjustment to specifications and standards (Green, 1994). Thus, it is possible saying that, nowadays, there is a strong and consolidated tendency to fulfill quality in HE according to an economicist perspective, if one considers the application of the higher education view focused on economy, on market and job creation, as well as on the diffusion of terms resulting from the industry and from the private sector to disseminate characteristics and properties of quality in the higher education.

\subsection{The Terms of the Pluralistic View of Quality in HE}

The idea that the higher education has the mission of developing diverse sociocultural and economic aspects of countries and societies (Unesco, 1998; Rodrigues Dias, 2004; Dias Sobrinho, 2005) is linked to the historical trajectory of universities during the XIX and XX centuries and to its relation with the State and the society. Accordingly, besides the economic matter, other aspects such as the cultural, social and democratic aspects-in a sustainable and balanced way, in countries and societies, are also considered important for higher education purposes. Such conception leads to observation concerning the specificities of each context and education system, as well as the respect to the existing differentiations in local, institutional and regional levels, since it does not prioritize one single mission in higher education. The members of the academic and scientific community, Unesco, the European Union and some governments, which are not completely committed with the neoliberal ideas, are among those who advocate for a greater plurality of missions in higher education. Documents from Unesco and from the European Union have shown the link between this education conception and the aspects of quality in HE through the use of terms such as "differentiation”, "relevance” and "pertinence”.

According to Morosini (2001), the European Union adopts the view of quality as differentiation. It is expressed through the development of pilot projects, through the recommendations of quality in higher education and the establishment of the "European Network for Quality Assurance in Higher Education" 2 . It is possible pinpointing the "Quality Evaluation of the School Education", among the pilot projects, which is based on self-evaluation to improve quality in more than 101 educational centers, in 18 European countries. The centers have autonomy to define their evaluation procedures, so that they can be adapted to these countries' development stage and contexts. The European Union Council launched recommendations regarding quality in HE, which highlight the respect to the autonomy of educational institutions during the evaluation process and the need of mechanisms to reflect the context they have been used in. The establishment of ENQA, which has the aim to promote the cooperation among the authors involved in the European evaluation process, may be considered as an observance action towards different realities. Regardless of the standardization guidelines of Bologna, it is possible observing the attention given to higher education specifications in each country in these three European Union movements, i.e. respect to autonomy, observance of diversity and, in the last instance, acceptance of the existing differentiation between institutions and contexts.

The document "Higher Education in the Twenty-First Century: Vision and Action", from the "World Conference on Higher Education” in 1998, highlights the need for avoiding uniformities; therefore, Unesco defines quality in higher education in a quite pluralistic manner:

[...] is a multidimensional concept, which should embrace all its functions, and activities: teaching and academic programmes, research and scholarship, staffing, students, buildings, facilities, equipment, services to the community and the academic environment. Internal self-evaluation and external review, conducted openly by independent specialists, if possible with international expertise, are vital for enhancing quality. Independent national bodies should be established and comparative standards of quality, recognized at international level, should be defined. Due attention should be paid to specific institutional, national and regional contexts in order to take into account diversity and to avoid uniformity. Stakeholders should be an integral part of the institutional evaluation process (Unesco, 1998; article 11, subparagraph a).

According to Unesco (1998), the relevance must regard the role and place of quality in society, its mission in education, research and services that result from it, as well as the viewpoint of its link with the world of labor in ${ }^{2}$ In a general conference of ENQA in November 4th 2004, the change of the term European Network to European Association was confirmed. Thus, from this date on, ENQA became the acronym for European Association for Quality Assurance in Higher Education (ENQA, 2005: p. 5). 
a broader sense, its relation with the State and with public financing sources, and its interaction with other levels and forms of teaching. All the subparagraphs in article 6 of "Higher Education in the Twenty-First Century: Vision and Action", deal with the relevance of higher education and highlight that:

[...] should be assessed in terms of the fit between what society expects of institutions and what they do. This requires ethical standards, political impartiality, critical capacities and, at the same time, a better articulation with the problems of society and the world of work, basing long-term orientations on societal aims and needs, including respect for cultures and environmental protection (Unesco, 1998; article 6, subparagraph a).

According to Estrada (1999), the word "relevance" means the relation between the institutional purposes and the real requirements and needs of society such as, for instance, coherence between the mission of an institution and the social demands of its coverage area. According to Fazendeiro (2002: p. 64), education, in order to have quality, must gather the desired and observable attributes in the dimension of "relevance", among others; since these attributes refer to "quality in terms of socially relevant results regarding the needs and expectations of individuals and of society in all their economic, social or cultural dimensions". Thus, based on the analysis of this definitions, it is possible stating that from the core of the higher education conception-concerning the diversity of missions and the purposes on projects of the European Union and on Unesco's positions-it raises an important tendency to the pluralistic view of quality in HE; fact that values the properties of differentiation, pertinence and relevance.

\subsection{The Terms of the Equity View of Quality in HE}

According to the document "Standards in Education: Fundamental Concepts", elaborated at "Latin American Laboratory for Assessment of the Quality of Education”, from Unesco (1997), the theme of “equity” is probably the main problem of nowadays public educational policies. According to Morosini, countries in the North of the European Union discuss HE quality in association with employability and diversity. At the same time:

Another group, actually a smaller one, emerges in the European panorama. This small group considers quality as synonym with equity.

The Instituto Nacional de Calidad y Evaluación (INCE), of the Education, Culture and Sports Ministry (from Spain), published some studies in Revista de Educación, on the theme Equidad y Calidad en Educación. Among such studies, there were two advocating for the previous ideas that quality and equity are inseparable concepts; and that the education community is responsible for the applicability and the success or fail of education policies regarding quality with equity. Nine key-factors are cited as a way to search for quality with equity: the extension of the education, the treatment given to diversity, school autonomy and the management of the centers, school direction, teachers, evaluation, innovation and the educational investigations. It is highlighted that quality goes beyond the standardization of indicators; it encompasses qualitative and quantitative studies (Morosini, 2001: p. 98).

The policies of the World Bank for many sectors and also for education are an attempt to pinpoint the concept of equity in order to promote economic development (World Bank, 2005). According to the bank's report about the Brazilian higher education:

Equity can mean different things, for example: i) a reasonable degree of equality of opportunity to participate in higher education and; ii) a reasonable and fair balance between paying the costs and obtaining the benefits from higher education (World Bank, 2001: p. 44).

However, McCowan (2005: p. 7) criticizes such definition since, by using the term "reasonable level", "the bank considers the total equality of opportunities as being either impossible or undesired to be achieved". He also considers that the second statement would hardly "fit" the first. Next, the author presents a definition considered to be less problematic than that of the World Bank by focusing on the minimum idea of equity as equality of opportunities. It is the conception suggested by H. Brighouse, and published in 2002 in Egalitarian liberalism and justice in education. According to such conception, in order to have education equity, those "with similar capacity level and with the will to do their best must have similar educational perspectives, regardless of their social background, ethnicity or gender" (apud McCowan, 2005). According to Mercedes G. García, equity un- 
derstood as one of the dimensions of the educational system means:

Making it possible to all the students, no matter their origin and conditions (personal, family or social), to have equal opportunities, processes and outcomes. It would be centered on the homogeneity of results, in all the geographic and social areas in a country or wherever one may observe differences in the access to or in the education process (just as it happens with gender), as a way to assure the compensation of differences or the equality of opportunities (García, 2000: p. 240).

In the document "Higher Education in the Twenty-First Century: Vision and Action" from Unesco, all the subparagraphs in article 3 deal with access equality and, notwithstanding, the document restated that the admission must be based on individual merit. The text highlights that, by considering the previously acquired competences, for the access to higher education "no discrimination can be accepted in granting access to higher education on grounds of race, gender, language or religion, or economic, cultural or social distinctions, or physical disabilities" (Unesco, 1998; article 3, subparagraph a).

In short, equity in higher education may encompass many aspects such as equality of access to opportunities for social groups, ethnicities, different regions in a country or even for the homogeneity level in the education provided by different educational institutions.

Many education evaluations and measures in different countries show the huge differences in results from distinct schools and regions. The small access less favored classes have to higher education clearly indicates the existing differences (Unesco, 1997). Thus, as education remains one of the main means of social mobility, it is worth struggling for educational equity. Within a context of severe social exclusion, such as that in Latin America, the emerging struggle against the educational iniquities becomes more incisive. Some political authors (Genro, 2005; Brovetto, 2005) and Latin-American scholars (Morosini, 2001) have alerted for the need to observe the iniquity issue in the educational systems and for its implication in the socio-economic inequalities, either in relation to national conjunctures or to the position of these countries in the world scenario. In the Meeting of the Intergovernmental Committee of the Main Education Project in Latin America and the Caribeans held in March 2001, the education ministers decided to adopt the Cochabamba Declaration, which clearly states the concept of quality as equity (Morosini, 2001). In short, the view of equity in the quality of HE is associated with the combat against the educational iniquities and, as consequence, to the search for social cohesion, to the development of democracy and to citizenship as priority of higher education.

\section{Conclusion: The Relentless Relativity of the Concept of Quality in HE}

The ways through which education has been approached have been historically changing, and it evidences the idea by Durkheim (1967) that education is a socialization process which integrates individuals within a social context. Therefore, it changes depending on the time and the environment. The term "quality", which results from then Latin word quails, means the type, caste, nature, character etc., its meaning has also changed in the education scope depending on the time and environment. According to Santiago (1999), it is undeniable that the original conceptions of quality and of "total quality" spread in the business and market competition environments are not completely absorbed by the higher education. Within this environment, quality is inexorably built due to the set of specificities of education institutions such as the academic autonomy and the limiting aspects that formalize the academic and scientific activities. Therefore, it is not possible adopting the concepts and quality programs originating from the industry and from the private sector in the higher education scope; it is also not possible to completely refuse quality by arguing that there is nothing in common between it and the higher education.

In the 1990s, OECD defined quality education as the one that "assured the acquisition of knowledge, capacity, skills and the necessary attitude by all youngsters in order to get prepared to adulthood". The document "The four pillars of education” from Unesco, which is elaborated by Delors (1999), rejects the mere instrumental and productivist view in education; it states that human's education must be organized according to four fundamental learning: learning to learn, learning to do, learning to live together and learning to be. As per Werthein (2003), who is Unesco's representative in Brazil, "these four pillars must be found in the education quality improvement policy, since they cover human beings as a whole, from the cognitive to the ethical, from the aesthetical to the technical, from the immediate to the transcendent. The view of totality integrates the modern conception of quality in education”. Despite such philosophical efforts, the understanding and the comprehension of 
quality in education are still the object of many studies and debates. According to Lemaitre (2005), the definitions of quality are not neutral or naive, since they refer to power balance in higher education and between the higher education and other social actors.

The term quality has been referenced and used in the higher education scope to justify many things: the changes in the curriculum, the research projects, the conferences and the scientific congresses etc. According to De la Orden Hoz (1997: p. 2), "all these activities and many others lie on the mantle of quality, because nobody can deny quality as an object of a project, of an institution or of an action program". In the early 1990s, Vroeijenstijn (1992) stated that "trying to define quality was a waste of time", he was based on the argument that it was a relative concept and that different stakeholders in higher education had different priorities and differentiated attention focus. The different classification propositions for quality conceptions in HE published in the 1990s (excellence, perfection, fitness for purpose, cost-benefit relation, transformation, adjustment to standards etc.) and the most recent terms applied to identify the priorities of quality (efficiency, employability, differentiation, relevance, pertinence, equity, among others) described in the herein performed literature review were symptomatic of great variability in the comprehension of quality in HE.

In fact, the statement that quality in education and, mainly, in higher education does not have one single meaning is vast in the literature of the last two decades:

In the modern world, there are not just two, but many different conceptions of higher education. This is how it should be, many would say. The pluralism of views regarding the aims of higher education is inevitable and results from the adequate reflection of a democratic society (Barnett, 1992).

The definitions of quality change and reflect distinct perspectives from individuals and from the society (Harvey \& Green, 1993).

Quality, just as liberty and justice, is an allusive concept (Green, 1994).

[...] the word quality is ambiguous and involves a series of values marked by particular references. Thus, quality means different things to distinct people (Estrada, 1999).

Quality is a complex, dynamic, historically built and multifaceted concept, which is often defined by what is missing than by the content (Unesco, 2003).

There is no pattern or a single recipe for a good quality school; quality is a dynamic concept, which is constantly rebuilt. Each school has the autonomy to reflect, suggest and act towards quality in education (Unicef, 2004).

With a wide variety of meanings and with variations linked to it, quality is an allusive term which is hard to define; thus, it is referred to as an 'unstable concept' (Sahney, Banwet, \& Karunes, 2004).

Quality in higher education is a multi-dimensional, multi-level and dynamic concept that is related to specifications of the context of an educational model, to the mission and institutional aims, as well as to the specific patterns within a certain system, institution, program or discipline. Quality may then have different meanings depending on: (i) the understanding from different groups or stakeholders interested in higher education; (ii) its references: inputs, process, output, missions, aims, etc.; (iii) attributes or features of the academic world that must be evaluated and; (iv) the historical periods of the higher education development (Vlãsceanu, Grünberg, \& Pârlea, 2004).

Quality is approached as a generic term and as a term specifically linked to monitoring in higher education (Harvey, 2004).

The conclusions in the studies about quality in HE tend to state that there are many, different and legitimate understandings of the term. Regardless of the level of analysis-classroom, course, institution or education system, the understanding of quality in HE may often change depending on time and on the environment. For some people, quality is a fundamental object in education; for others, it may stop existing. For some, it can be measured; for others, it can be "operationalized". For market agents, it must prioritize "employability"; for the social movements, it must prioritize equity. Ultimately, it is perfectly possible that quality in HE has a meaning to a group and, at the same time, another meaning (quite distinct from the other) to other groups. The fact is that the understanding of quality is inexorably subjective, since it fundamentally depends on the conceptions of world and of higher education by those who spread it. It has been like that in the last few decades, and it is still the same in the early XXI century. Thus, it will probably remain the same in the next years to come. 


\section{References}

Amaral, A. (2002). The Management of Universities and Representatives of External Stakeholders. Jornal a Página, 11, 27.

Barnett, R. (1992). Improving Higher Education-Total Quality Care. Bristol: SRHE and Open University Press.

Bertolin, J. C. G. (2007). Quality Assessment of the Brazilian Higher Education System in Marketization Times-From 1994 to 2003. PhD Thesis, Porto Alegre: Federal Universityof Rio Grande do Sul.

Brazil (2003). National Examination Course 2003 Report-Synthesis Report. National Institute for Educational Studies and Research “Anísio Teixeira”, Brasília: Inep.

Brovetto, J. (2005). New Challenges in Higher Education in Latin America. In Brazil/NationalInstitute for Educational Studies and Research "Anísio Teixeira” Inep, InternationalSeminary "Reforma e avaliação da educação superior-Tendências na europa e américa latina”. Brasília: Inep.

De la Orden Hoz, A., et al. (1997). Development and Validation of a University's Quality Model as a Basis for Evaluation. Revista Electrónica de Investigación y Evaluación Educativa, 3, 1-2.

Delors, J. (1999). Learning: The Treasure Within. São Paulo: Cortez/MEC/Unesco.

Dias Sobrinho, J. (2005). Dilemmas of Higher Education in a Globalized World: The Knowledge Society and Knowledge Economy. São Paulo: Casa do Psicólogo.

Durkheim, É. (1967). The Evolution of Educational Thought. Porto Alegre: Art Méd.

Estrada, L. R. G. (1999). Towards a Model of Assessment in Higher Education Institutions. Revista Iberoamericana de Educación, 21, 93-106.

European Association for Quality Assurance in Higher Education-ENQA (2005). Standards and Guidelines for Quality Assurance in the European Higher Education Area. Helsinki: ENQA.

Fazendeiro, A. (2002). Education Quality Assessment: An Approach Based on the Planning. In CNE (Ed.), Qualidade e avaliação da educação. Seminários e Colóquios. Lisboa: CNE—Ministério da Educação.

García, M. G. (2000). Assessment and Quality of the Education Systems. In T. G. Ramírez (Ed.), Assessment and Management of Education Quality (pp. 227-268). Málaga: Ediciones Aljibe.

Genro, T. (2005). The Reform of Higher Education in Brazil. In Brazil/National Institute for Educational Studies and Research “Anísio Teixeira”-INEP (Ed.), International Seminary "Reforma e avaliação da educação superiorTendências na europa e américa latina”. Brasília: INEP.

Gentilli, P., \& Silva, T. T. (1995). Neoliberalism, Total Quality and Education (2nd ed.). Petrópolis: Vozes.

Green, D. (1994). What Is Quality in Higher Education? Bristol: SRHE and Open University Press.

Harvey, L. (2002). The End of Quality? Quality in Higher Education, 8, 5-22. http://dx.doi.org/10.1080/13538320220127416

Harvey, L. (2004). Analytic Quality Glossary. http://www.qualityresearchinternational.com/glossary/

Harvey, L. (2005). A History and Critique of Quality Evaluation in the UK. Quality Assurance in Education, 13, $263-276$. http://dx.doi.org/10.1108/09684880510700608

Harvey, L., \& Green, D. (1993). Defining Quality. Assessment \& Evaluation in Higher Education, 18, 9-26. http://dx.doi.org/10.1080/0260293930180102

Leite, D. (2003). Institutional Evaluation, Reorganizations e Capitalist Redesign of Universities. In J. Dias Sobrinho, \& D. Ristoff (Eds.), Assessment and Public Commitment (pp. 53-76). Florianópolis: Insular.

Lemaitre, M. J. (2005). The Colonized Quality: University and Globalization. Revista de la Educación Superior, 34, 123134.

McCowan, T. (2005). The Growth of Private Higher Education in Brazil: Implications for Issues of Equity, Quality and Public Benefit. Arquivos Analíticos de Políticas Educativas, 13, 1-20. http://dx.doi.org/10.14507/epaa.v13n27.2005

Mizikaci, F. (2006). A Systems Approach to Program Evaluation Model for Quality in Higher Education. Quality Assurance Education, 14, 37-53. http://dx.doi.org/10.1108/09684880610643601

Morosini, M. C. (2001). The Quality of Higher Education: Isomorphism, Diversity and Fairness. Interface-Comunicação, Saúde, Educação, 5, 89-102. http://dx.doi.org/10.1590/S1414-32832001000200006

Organisation Economic Co-Operation and Development-OECD (1999). Quality and Internationalisation in Higher Education. Programme on Institutional Management in Higher Education-IMHE, Paris: OECD.

Rodrigues Dias, M. A. (2003). Trade in Higher Education: Can We Maintain the Idea of Public Good? Revista Educação \& Sociedade, 24, 817-838. 
Sahney, S., Banwet, D. K., \& Karunes S. (2004). Conceptualizing Total Quality Management in Higher Education. The TQM Magazine, 16, 145-159. http://dx.doi.org/10.1108/09544780410523044

Sander, B. (1995). Management Education in Latin America: Construction and Reconstruction of Knowledge. Campinas: Editora Autores Associados.

Santiago, R. (1999). The Concept of Quality in Higher Education. In Encontro INA (Ed.), A Avaliação na Administração Pública. Lisboa: Instituto Nacional de Administração.

Santos, B. de S. (2004). The University in the Twenty-First Century. Towards a Democratic and Emancipatory University Reform. São Paulo: Cortez.

United Nations Children’s Fund-Unicef (2004). Quality Indicators in Education. São Paulo: Ação Educativa.

United Nations Educational, Scientific and Cultural Organization-Unesco (1997). Standards in Education: Fundamental Concepts. Documents-Latin American Laboratory for Assessment of the Quality of Education. Chile: Lecce/Orealc/ Unesco.

United Nations Educational, Scientific and Cultural Organization-Unesco (1998). Higher Education in the Twenty-First Century: Vision and Action. World Conference on Higher Education. Paris: Unesco.

United Nations Educational, Scientific and Cultural Organization-Unesco (2003). Quality of Higher Education—Comission II. Paris: Unesco.

Vlãsceanu, L., Grünberg, L., \& Pârlea, D. (2004). Quality Assurance and Accreditation: A Glossary of Basic Terms and Definitions. Bucharest: Unesco-Cepes Papers in Higher Education.

Vroeijenstijn, T. (1992). External Quality Assessment, Servant of Two Masters? The Netherlands University Perspective. In A. Craft (Ed.), Quality Assurance in Higher Education (pp. 109-131). Lewes: Falmer Press.

Watty, K. (2005). Quality in Accounting Education: What Say the Academics? Quality Assurance in Education, 13, $120-131$. http://dx.doi.org/10.1108/09684880510594373

Werthein, J. (2003). Education: The Challenge of Quality. http://www.unesco.org.br/noticias/opiniao/artigow/artigow qual/mostra documento

World Bank (2001). Higher Education in Brazil: Challenges and Options. Washington DC: World Bank Publications.

World Bank (2002). Constructing Knowledge Societies: New Challenges for Tertiary Education. Washington DC: World Bank Publications.

World Bank (2005). World Development Report 2006: Equity and Development (Vol. 28). Washington DC: World Bank Publications. http://dx.doi.org/10.1596/978-0-8213-6249-5 